\title{
Global virtual-land flow and saving through international cereal trade
}

\author{
ZHANG Jingqi ${ }^{1}$, "ZHAO Naizhuo ${ }^{2}$, LIU Xingjian ${ }^{3}$, LIU Ying ${ }^{2}$ \\ 1. School of Humanity and Law, Northeast University, Shenyang 110169, China; \\ 2. Department of Geosciences, Texas Tech University, Lubbock, TX 79409, USA; \\ 3. Department of Urban Planning and Design, University of Hong Kong, Hong Kong, China
}

\begin{abstract}
With intense urbanization and sustained population growth, securing food production with limited land sources has increasingly become a pressing issue. Based on an analysis of international cereal (i.e., barley, buckwheat, maize, oats, rice, rye, sorghum, soybean, and wheat) trade and differences in yields of the cereal between export and import countries over the period of 2007 to 2011, we explore the great potential of land saving through the international cereal trade. By 'land saving', we refer to the reduced global total of lands required to produce a necessary amount of cereal when cereal is exported from a country with relatively large yield of the cereal to a country with relatively small yield of the cereal. Our scenario analysis suggests that international cereal trade would help mitigate the shortage of domestic arable land for many island countries (e.g., Japan) and countries in the arid Middle East and North Africa (e.g., Syria and Morocco). Furthermore, international cereal trade has the potential to generate 'land saving' of 50,092,284 ha of land per year, which is roughly the size of Spain. Drawing upon the definition of a similar concept - virtual water (Hoekstra and Hung 2002), we define virtual land as the area of land resources used for the production of goods. Through introducing the concept of virtual land, we believe land resources that are traditionally considered as stationary resources can flow with anthropogenic socioeconomic activities. The largest virtual-land flows (> 3,000,000 ha/year) exist between the United States (US) to China, Brazil to China, the US to Japan, the US to Mexico, and Argentina to China. However, not all virtual-land flows necessarily result in land saving. Thus, more endeavors are needed to plan the virtual-land flows for a larger land saving at the global scale.
\end{abstract}

Keywords: virtual land; land saving; land flow; international cereal trade

\section{Introduction}

Tackling the problem of supporting a rapidly growing population with increasingly limited natural resources is of vital importance for humankind. With intensified global connections and socioeconomic integration, scholars have begun to realize the potential of international

Received: 2015-05-15 Accepted: 2015-07-31

Foundation: National Social Science Foundation of China, No.15CGL078

Author: Zhang Jingqi (1982-), Associate Professor, specialized in GIS \& RS application of urban governance.

E-mail: daqi00@163.com

"Corresponding author: Zhao Naizhuo (1981-), specialized in GIS \& RS application. E-mail: naizhuo.zhao@ttu.edu 
trade as a venue for saving natural resources (Chapagain et al., 2006; Hoekstra and Chapagain, 2008; Fader et al., 2011). As a case in point, Hoekstra and colleagues (Hoekstra and Hung, 2002; Chapagain and Hoekstra, 2004; Chapagain et al., 2006; Hoekstra and Chapagain, 2007) have developed water footprint theory and proposed the concept of virtual water: the amount of freshwater that is consumed to produce goods (Hoekstra and Chapagain, 2007). Water saving can occur when a commodity is shipped from a site with relatively high to another site with relatively low water productivity (Chapagain et al., 2006). Following the definition of virtual water, we define virtual land as the area of land resources used throughout the production processes of the goods. In a sense when a country is importing/exporting goods, it is essentially importing/exporting the land used to produce these goods. In other words, land resources can 'flow' when commodities are traded from one country/region to another. Moreover, as countries' productivity varies, producing the same commodities would require different amounts of land resources in different countries. These differences in required virtual land to produce certain goods allow for the possibility of land savings through trade at the global scale: we may produce more commodities with the existing amount of land resources or we may sustain the current level of production with less land resources. Such land savings would take place when commodities are traded from a country with more efficient land uses to a country with less efficient land uses. For example, producing 1 ton of wheat needs 0.35 ha of land per year in India but only 0.15 ha of land per year in France (FAO, 2014). If India imports 1 ton of wheat from France, at the national level India saves 0.35 ha of land while at the global scale 0.20 ha land resources are saved.

Cereal commodities are land-intensive and in high-demand. With existing land resources and cereal production capacity, a serious shortage of cereal supply will emerge in 2050 when global population is projected to be $50 \%$ larger than at present (Tilman et al., 2002). Since land resources are limited on earth, saving more land resources means additional cereal or other foods can be produced. Therefore, in addition to endeavors to improve the yield of grains, it is necessary to exploit the potential of land saving through international cereal trade. Many previous studies have shown that a certain volume of water resources can be saved by agricultural trade (Fraiture et al., 2004; Chapagain et al., 2006; Fader et al., 2011; Dalin et al., 2012), but very limited studies were performed on land saving through international trade. Würtenberger et al. (2006) and Qiang et al. (2013) have discussed country-specific land saving through agricultural trade for Switzerland and China respectively. Meanwhile, Fader et al. (2011) analyzed global land saving through agricultural trade during 1998 to 2002 however their analysis focused more on water footprints and water resources saving. Thus there exists a large lacuna in research on land saving/loss through international cereal trade at the global and the national levels.

The main objectives of this study are to investigate global virtual-land flows related to international cereal trade over recent five years (2007-2011) and explore land saving/loss generated by the cereal trade. To fulfill these objectives, we first select nine major cereals (i.e. barley, buckwheat, maize, oats, rice, rye, sorghum, soybean, and wheat). Then, we calculate and illustrate specific areas of land saving/loss led by trade of the nine cereals at the national and the global levels. Next, we discuss each country/region's dependency on external virtual land. Finally we analyze major virtual-land flows related to cereal trade between large virtual-land-export and virtual-land-import countries and land saving/loss derived from 
the major virtual-land flows at the global scale.

\section{Data and method}

Our analysis focuses on nine major cereals (i.e., barley, buckwheat, maize, oats, rice, rye, sorghum, soybean, and wheat). A comprehensive dataset of production and trade of the nine kinds of cereals was obtained from the FAOSTAT that is established by the Food and Agriculture Organization of the United Nations (FAO) (2014). The dataset had the following variables for each country during 2007 to 2011: yield, harvested area, import quantity, and export quantity.

A country's import/export quantity of cereals may vary greatly in different years. For example, China (here and hereafter referring to mainland China) exported 2,336,620 tons of wheat in 2007 but only 12 tons in 2010. Pakistan imported 1925 tons of rice in 2010 but in 2011 the imported quantity of rice by Pakistan rocketed to 21,052 tons. To obtain stable patterns of virtual-land flow and land saving/loss through international cereal trade of a country or the globe, we averaged data of cereal production and trade for the five-year study period (i.e. 2007 to 2011). At the national level virtual land can be saved or lost by importing or exporting cereals and so in this study imported virtual land $\left(I V L_{c}\right)$ and exported virtual land $\left(E V L_{c}\right)$ were calculated by equations 1 and 2 respectively:

$$
\begin{aligned}
I V L_{C}= & \frac{\sum_{y=1}^{5} \sum_{i=1}^{9} \frac{I_{c, i, y}}{Y e_{c, i, y}}}{5} \\
E V L_{C} & =\frac{\sum_{y=1}^{5} \sum_{i=1}^{9} \frac{E_{c, i, y}}{Y e_{c, i, y}}}{5}
\end{aligned}
$$

where $I_{c, i, y}$ and $E_{c, i, y}$ represent import and export quantities of cereal $i$ of country $c$ in the year $y$ respectively, and $Y e_{c, i, y}$ represent yield of cereal $i$ of country $c$ in the year $y$. A county's net land saving through cereal trade $\left(N L S_{c}\right)$ is calculated by equation 3:

$$
N L S_{c}=I V L_{c}-E V L_{c}
$$

If $N L S_{c}$ is larger than 0 , it indicates the country $c$ saved land resources through cereal trade. If $N L S_{c}$ is smaller than 0 , it indicates the country $c$ lost land resources through cereal trade.

At the global level virtual land can be saved through cereal trade when cereals are shipped from countries with more efficient land uses to countries with less efficient land uses. Consequently, global total virtual-land saving (GNLS) was computed by equation 4:

$$
G N L S=\sum_{i=1}^{9} G N L S_{i}=\sum_{i=1}^{9}\left(\frac{\sum_{y=1}^{5}\left(\sum_{c=1}^{n} \frac{I_{c, i, y}}{Y e_{c, i, y}} \sum_{c=1}^{n} \frac{E_{c, i, y}}{Y e_{c, i, y}}\right)}{5}\right)
$$

where $G N L S_{i}$ is saved virtual land through international trade of cereal $i$ and $n$ represents the number of countries involved in the international cereal trade during 2007 to 2011. If GNLS is smaller than 0, it implies that in most international trades cereals were shipped from less-efficient-land-use countries to more-efficient-land-use countries and consequently virtual-land loss rather than virtual-land saving occurred through international cereal trade. A 
few countries imported or exported cereals during 2007 to 2011 but lack corresponding data of yields. We assumed that yields of the cereals in such countries are global average yields of the cereals. The countries lacking yield data nearly all have very small import/export quantity of cereals, so our assumption did not generate substantial impacts on GNLS.

To further analyze impacts of international cereal trade on demand of a country, we calculated each country's external land dependency $\left(E L D_{c}\right)$ by equation 5 :

$$
E L D_{c}=\frac{\sum_{y=1}^{5}\left(\frac{\sum_{i=1}^{9} \frac{l_{c, y, i}}{Y e_{c, y, i}}}{\sum_{i=1}^{9} H A_{c, y, i}}\right)}{5}
$$

where $H A_{c, y, i}$ represents harvested area of cereal $i$ of the country $c$ in the year $y$. Hence, the larger an external land dependency (ELD) of a country, the more dependent the country is on international cereal trade and other countries' land resources.

To map major virtual-land flows, we calculated the area of virtual land flowing between each two trading partners of cereal by equation 6 :

$$
V I_{e c-i c}=\frac{\sum_{y=1}^{5} \sum_{i=1}^{9} \frac{E_{e c-i c, i, y}}{Y e_{e c, i, y}}}{5}
$$

where $V L_{e c-i c}$ denotes the area of virtual land exported from the country of $e c$ to the country of $i c, E_{e c-i c, i, y}$ denotes export quantities of cereal $i$ from the country ec to the country $i c$ in the year $y$, and $Y e_{e c, i, y}$ represents yield of cereal $i$ of the export country $e c$ in the year $y$. We also calculated net land saving generated by the individual land flow between each two trading partners $\left(N L S_{e c-i c}\right)$ by equation 7:

$$
N L S_{e c-i c}=\frac{\sum_{y=1}^{5} \sum_{i=1}^{9}\left(\frac{E_{e c-i c, i, y}}{Y e_{i c, i, y}}-\frac{E_{e c-i c, i, y}}{Y e_{e c, i, y}}\right)}{5}
$$

A positive value of $N L S_{e c-i c}$ indicates that land resources are saved by the cereal trade between the two countries. Otherwise, land resources are lost by the trade at the global scale.

\section{Results}

\subsection{Virtual-land flow and saving/loss at the national level}

During 1997 to 2011, 201 countries (or regions) were involved in international cereal trade when 167 countries (or regions) saved land resources while 34 countries (or regions) lost land resources through the international cereal trade (Table 1 in appendix). China, Japan, Mexico, Morocco, Algeria, Venezuela, Germany, Spain, the Republic of Korea, and the Netherlands are the largest virtual-land-import countries. Imports of soybean, maize and/or wheat greatly shape the imported virtual land of the ten countries (Figure 1). Eight of the ten countries (i.e., China, Japan, Mexico, Morocco, Algeria, Venezuela, Republic of Korea, and Spain) have the largest net land-saving values and consequently saved the largest areas of land resources through cereal trade. Although they imported very large amounts of virtual 
land, Germany and the Netherlands also exported large areas of virtual land $(1,527,475$ ha and 895,418 ha, respectively). Indonesia and Nigeria replace Germany and the Netherlands and become the ninth and the tenth largest land-saving country respectively through cereal trade (Table 1).

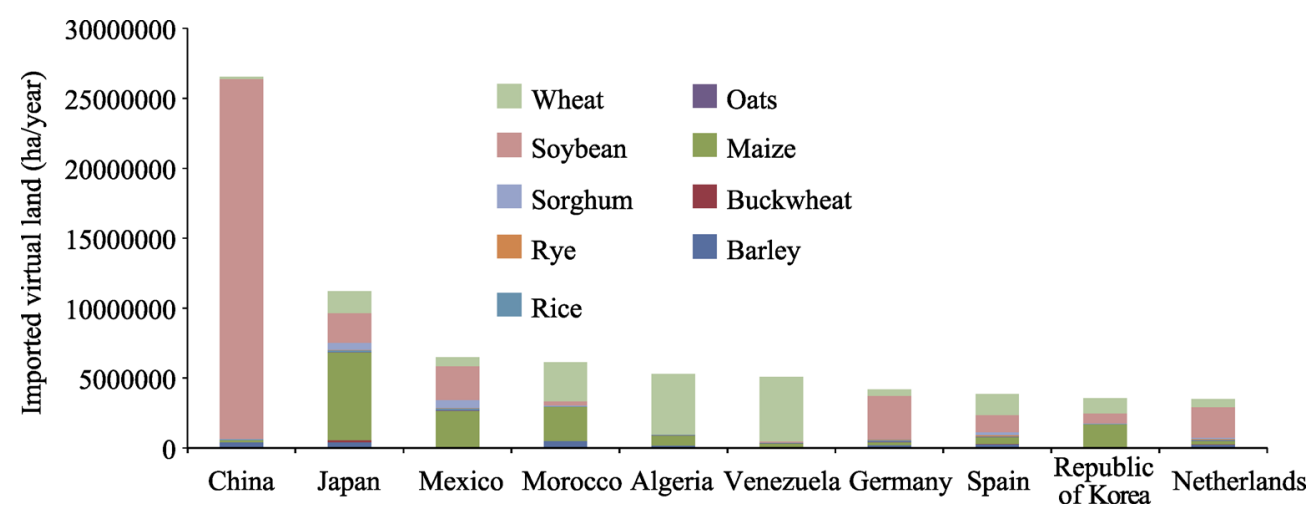

Figure 1 Imported virtual lands for the ten largest virtual-land-import countries

Table 1 Net land saving for ten countries with the largest land saving through international cereal trade (ha/year)

\begin{tabular}{|c|c|c|c|c|c|c|c|c|c|c|}
\hline Country & Barley & $\begin{array}{l}\text { Buck- } \\
\text { wheat }\end{array}$ & Maize & Oats & Rice & Rye & Sorghum & Soybean & Wheat & Sum \\
\hline $\begin{array}{l}\text { China, } \\
\text { mainland }\end{array}$ & 428978 & -81671 & -88827 & 12896 & -63483 & 0 & -21012 & 25557987 & 36922 & 25781790 \\
\hline Japan & 431432 & 128429 & 6279733 & 33427 & 105190 & 38876 & 493419 & 2134916 & 1556441 & 11201864 \\
\hline Mexico & 37174 & 0 & 2552578 & 67634 & 121105 & 59 & 574826 & 2422318 & 474403 & 6250096 \\
\hline Morocco & 508002 & 1 & 2480014 & 611 & 1271 & 0 & 70869 & 282336 & 2794927 & 6138032 \\
\hline Algeria & 177007 & 0 & 738516 & 3328 & 53429 & 0 & 109 & 51 & 4311183 & 5283623 \\
\hline Venezuela & 22 & 0 & 362312 & 259 & 30788 & 1 & 275 & 64168 & 4631608 & 5089433 \\
\hline $\begin{array}{l}\text { Republic } \\
\text { of Korea }\end{array}$ & 15523 & 2524 & 1688240 & 1622 & 45090 & 3508 & 3693 & 722724 & 1064366 & 3547290 \\
\hline Spain & 204313 & 134 & 469809 & 24364 & -13070 & 72180 & 224056 & 1211139 & 1342817 & 3535743 \\
\hline Indonesia & 12.47045 & 1 & 261584 & 217 & 218708 & 1778 & 332 & 1281372 & 1561662 & 3325665 \\
\hline Nigeria & 161 & 346 & -1068 & 9 & 869775 & 0 & 7923 & -14962 & 2144898 & 3007082 \\
\hline
\end{tabular}

During 2007 to 2011, 116,390,949 ha/year virtual land was exported and $81.21 \%$ of the exported virtual land was derived from ten countries (i.e., the United States, Brazil, Australia, Argentina, Canada, Russia, Ukraine, Kazakhstan, France, and Thailand). Exports of soybean, maize, wheat, or barley massively shape exported virtual land of the ten countries except Thailand (Figure 2). Exported virtual land of Thailand is mostly derived from exports of rice. Due to the very large exported virtual land, nine of the ten largest virtual-land-export countries (i.e., the United States, Australia, Brazil, Argentina, Canada, Russia, Ukraine, Kazakhstan, and France) experienced the largest net land loss in the world. India is the other top 10 net-land-loss country because of its very large net virtual-land loss in exports of maize and rice (Table 2).

\subsection{Virtual-land flow and saving at the global level}

During 1997 to 2011 global total harvested area per year of the nine kinds of cereals is 


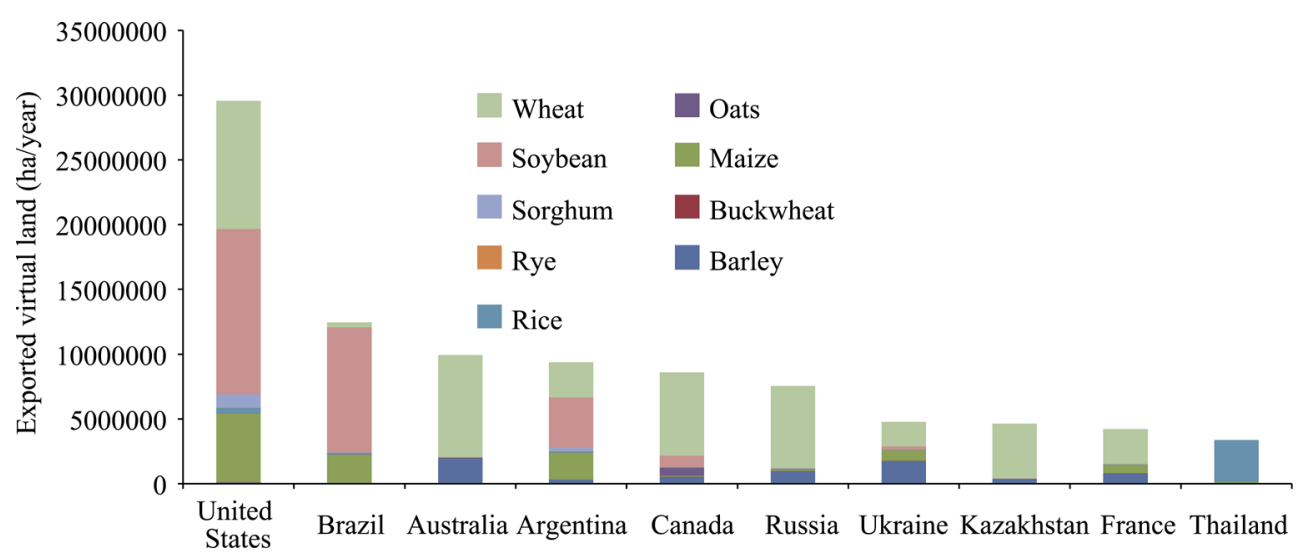

Figure 2 Exported virtual lands for the ten largest virtual-land-export countries

Table 2 Net land saving for ten countries with the largest land loss through international cereal trade (ha/year)

\begin{tabular}{lrrrrrrrrrr}
\hline \multicolumn{1}{c}{ Country } & Barley & $\begin{array}{l}\text { Buck- } \\
\text { wheat }\end{array}$ & Maize & Oats & Rice & Rye & Sorghum & Soybean & Wheat & Sum \\
\hline US & 17653 & -15496 & -5260252 & 777382 & -332477 & 72504 & -1048653 & -12613184 & -9089213 & -27491736 \\
Australia & -1909820 & 232 & -2971 & -112716 & 6837 & -830 & -17183 & -212 & -7885973 & -9922634 \\
Brazil & 108130 & -186 & -2048760 & -3014 & 9416 & 26 & -19919 & -9648151 & 2106069 & -9496388 \\
Argentina & -314566 & 0 & -2120317 & -887 & -79277 & 6 & -301830 & -3414157 & -2697611 & -8928639 \\
Canada & -512797 & -1443 & 145415 & -634845 & 95259 & -66811 & 1658 & -741034 & -6400894 & -8115493 \\
Russia & -905298 & -2556 & -104323 & -1536 & 32739 & -26595 & -507 & 591841 & -6275804 & -6692039 \\
Ukraine & -1767875 & -715 & -819118 & -4835 & 13319 & -15713 & -25763 & -240754 & -1897307 & -4758761 \\
Kazakhstan & -329121 & -1269 & -521 & -3831 & -3027 & -497 & 1 & 4171 & -4221700 & -4555794 \\
France & -811921 & 3145 & -600686 & -10832 & 73780 & -4268 & 6414 & 196389 & -2618306 & -3766286 \\
India & -61129 & 371 & -1276268 & 2859 & -1088450 & -473 & -82869 & -21869 & 188562 & -2339266 \\
\hline & & & & & & & & &
\end{tabular}

$755,549,880$ ha, $15.4 \%$ of which (i.e., $116,390,949 \mathrm{ha})$ was exported as virtual land and consequently led to 50,092,284 ha/year virtual-land saving at the global scale. In other words, without the international cereal trade, an additional $50,092,284$ ha of land, almost equal to the area of Spain, was needed to meet the demand for cereal in one year. Figure 3 shows that trade of soybean, maize and wheat have the largest contributions to global land saving. International trade of soybean, maize and wheat led to exports of $30,904,124$

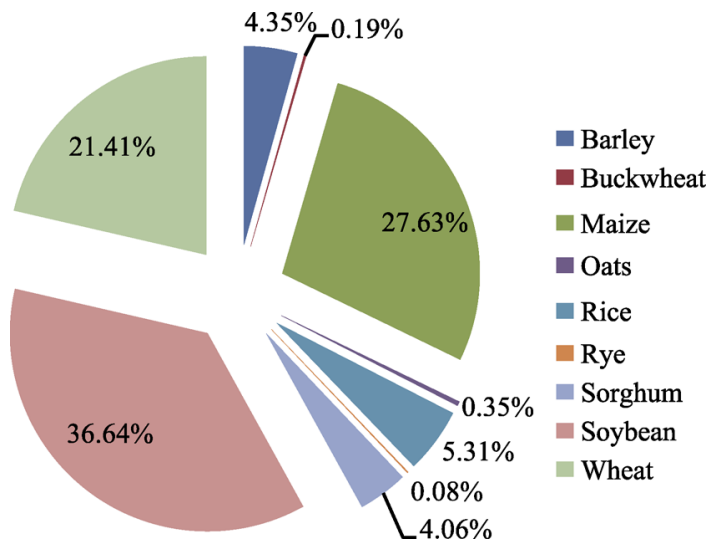

Figure 3 Contributions of different cereals to global land saving ha/year, 16,262,145 ha/year, and 48,994,862 ha/year virtual land, and consequent land saving of 18,353,082 ha/year, 13,838,961 ha/year, and 10,724,783 ha/year respectively. Trade of rice, barley, and sorghum also considerably contribute to land saving. With international trade of rice, barley, and sorghum 8,144,730 ha/year, 8,721,120 ha/year, and 1,761,535 
ha/year virtual land was exported from 143 countries to 202 countries respectively which resulted in land saving of 2,658,103 ha/year, 2,177,040 ha/year, and 2,032,291 ha/year respectively. Relatively small virtual land was exported with international trade of oats, buckwheat, and rye and consequently relatively small areas of land resources of 2,658,103 ha/year, 92,752 ha/year, and 40,242 ha/year were saved from the trade of the three kinds of cereal respectively (Table 3 ).

Table 3 Virtual-land saving and land-saving efficiency for different cereals (ha/year for harvested area, imported virtual land, exported virtual land, and saved virtual land)

\begin{tabular}{lccccccccccc}
\hline & Barley & $\begin{array}{c}\text { Buck- } \\
\text { wheat }\end{array}$ & Maize & Oats & Rice & Rye & Sorghum & Soybean & Wheat & Sum \\
\hline $\begin{array}{l}\text { Harvested } \\
\text { area }\end{array}$ & 52244089 & 2277652 & 163321757 & 10442451 & 159725031 & 5991368 & 42842243 & 98516364 & 220188925 & 755549880 \\
$\begin{array}{l}\text { Imported } \\
\text { virtual land }\end{array}$ & 10898160 & 235887 & 30101106 & 1226827 & 10802834 & 447742 & 3793826 & 49257205 & 59719646 & 166483233 \\
$\begin{array}{l}\text { Exported } \\
\text { virtual land }\end{array}$ & 8721120 & 143135 & 16262145 & 1051797 & 8144730 & 407500 & 1761535 & 30904124 & 48994862 & 116390949 \\
$\begin{array}{l}\text { Saved } \\
\text { virtual land }\end{array}$ & 2177040 & 92752 & 13838961 & 175030 & 2658103 & 40242 & 2032291 & 18353082 & 10724783 & 50092284 \\
$\begin{array}{l}\text { Land-saving } \\
\text { efficiency }\end{array}$ & 0.25 & 0.65 & 0.85 & 0.17 & 0.33 & 0.10 & 1.15 & 0.59 & 0.22 & 0.43 \\
\hline
\end{tabular}

Note: Land-saving efficiency=Saved virtual land/exported virtual land

Although the largest virtual-land export derived from wheat trade (Table 3), trade of soybean and maize led to the largest virtual-land savings (Figure 3). That is because land-saving efficiency varies greatly for different cereals. In other words, when the same area of virtual land involved in different cereals is exported, the area of land saving is different. It can be seen (Table 3) that sorghum has the largest land-saving efficiency. During 2007 to 2011, $1,761,535 \mathrm{ha} /$ year virtual land was exported with sorghum trade resulting in 2,032,291 ha/year land saving with land-saving-efficiency of 1.15. Compared to sorghum, oats and rye have very small land-saving efficiencies that are only 0.17 and 0.10 respectively (Table 3 ). Rice, barley, and wheat have medium land-saving efficiencies that are $0.33,0.25$, and 0.22 respectively. Although sorghum has a very large land-saving efficiency, its demand (i.e., an export quantity of $6,483,235$ ton/year) is not very large. Soybean and maize both have relatively large land-saving efficiencies ( 0.59 and 0.85 respectively) and very large demands (export quantities of 84,521,025 ton/year and 106,061,257 ton/year respectively), so international trade of soybean and maize contributed to the largest virtual-land savings in the trade of the nine kinds of cereals.

\section{Discussion}

\subsection{External land dependency}

Globally there are 167 net virtual-land import countries with positive net-land-saving values through cereal trades, 62 of which exported virtual land larger than their domestic land producing cereals in area. Countries greatly dependent on international cereal trade (i.e. having very large ELD) are mostly located in West Asia (e.g. United Arab Emirates with ELD of 392, Qatar with ELD of 219, and Kuwait with ELD of 159) or North Africa (e.g., Djibouti with ELD of 12680), or are island nations (e.g., Mauritius with ELD of 969, Maldives with ELD of 89, and Papua New Guinea with ELD of 44) (Table 2 in appendix). These countries 
have to import a large area of virtual land to meet domestic demand on land resources due to their scarce lands suitable for cultivation or limited territories. Additionally, 24 countries/regions imported virtual land from international cereal trade but did not have any domestic land planting cereals. The 24 countries/regions (e.g. Bahrain, Hong Kong, Iceland, and Singapore) are nearly all island nations/regions (Table 2 in appendix).

It should be noted that as the largest population country China's ELD is only 0.2688 . As the second largest population country India's ELD is -0.0238 , which implies that India nearly need not import virtual land to meet domestic demand on cereal and even can export virtual land for other countries. As the third largest population country, the United States is the largest virtual-land export (and net virtual-land export) country. Even though having the largest populations, India, China, and the United States also have the largest domestic arable lands $(98,280,538$ ha, 95,926,026 ha, and 88,441,963 ha respectively) in the world. Thus, compared to population, domestic arable land may have greater impacts on virtual-land flow. In 2007 and 2008 China could export a considerably large amount of maize and wheat to the Democratic People's Republic of Korea, Japan, and the Republic of Korea. These exports from China partly contribute to the adequate supply of cereal in global markets. However, with exceptional economic growth China's demand on virtual land has increased remarkably. Since 2009 China has become a wheat net-import country and in 2010 China's imported amount of maize began to be larger than its exported amount of maize. Moreover, the amount of soybean that China imported from the global markets increased massively during the period of 2007-2011. The changes in the balance of China's cereal import and export resulted in an apparent increase in net imported virtual land in China (Table 4). Therefore, affluence is likely to be another dynamic of virtual-land flow.

Table 4 Changes of net imported virtual land in China from 2007 to 2011 (ha)

\begin{tabular}{lrrrrr}
\hline & 2007 & 2008 & 2009 & 2010 & 2011 \\
\hline Barley & 220342 & 298505 & 465964 & 607120 & 552957 \\
Buckwheat & -94986 & -71850 & -77311 & -95506 & -68703 \\
Maize & -944805 & -36605 & -8739 & 264705 & 281310 \\
Oats & 1730 & 9410 & 14739 & 19229 & 19373 \\
Rice & 129463 & 99606 & 65213 & 35975 & -12840 \\
Rye & 0 & 0 & 0 & 0 & 0 \\
Sorghum & -60852 & -28967 & -7329 & 8834 & -16744 \\
Soybean & 20885180 & 21711957 & 25891107 & 30847583 & 28454109 \\
Wheat & -489017 & -19756 & 186814 & 256646 & 249923 \\
Sum & 19647056 & 21962301 & 26530458 & 31944586 & 29459385 \\
\hline
\end{tabular}

\subsection{Major virtual-land flows and their contribution to global land saving}

The largest two virtual-land flows generated by cereal trade exist between the United States to China and Brazil to China. At the national level the United States and Brazil lost $6,925,492 \mathrm{ha} /$ year and 5,385,085 ha/year land resources respectively due to the cereal export to China. However, 11,574,575 ha and 9,136,082 ha lands are needed per year to produce the same amount of imported cereal if the cereals were produced in China. Hence, at the global scale 4,649,083 ha/year and 3,750,997 ha/year land resources were saved through cereal trade from the United States and Brazil to China. Table 5 shows that the United States and 
Table 5 The 11 largest virtual-land flows $(>1,000,000$ ha/year) and land saving generated by the 11 individual virtual-land flows (ha/year)

\begin{tabular}{|c|c|c|c|c|c|c|c|c|c|c|c|}
\hline & & Barley & $\begin{array}{l}\text { Buck- } \\
\text { wheat }\end{array}$ & Maize & Oats & Rice & Rye & $\begin{array}{l}\text { Sor- } \\
\text { ghum }\end{array}$ & Soybean & Wheat & Sum \\
\hline \multirow{3}{*}{$\begin{array}{l}\text { From } \\
\text { the US } \\
\text { to } \\
\text { China }\end{array}$} & $\begin{array}{l}\text { Produced in } \\
\text { the US }\end{array}$ & 0 & 9 & 94321 & 0 & 300 & 169 & 449 & 6755511 & 74733 & 6925492 \\
\hline & $\begin{array}{l}\text { Produced in } \\
\text { China }\end{array}$ & 0 & 10 & 157551 & 0 & 350 & 106 & 488 & 11369400 & 46670 & 11574575 \\
\hline & Land saving & 0 & 1 & 63230 & 0 & 50 & -63 & 39 & 4613889 & -28063 & 4649083 \\
\hline \multirow{3}{*}{$\begin{array}{l}\text { From } \\
\text { Brazil to } \\
\text { China }\end{array}$} & $\begin{array}{l}\text { Produced in } \\
\text { Brazil }\end{array}$ & 0 & 0 & 8061 & 0 & 0 & 0 & 0 & 5375671 & 1353 & 5385085 \\
\hline & $\begin{array}{l}\text { Produced in } \\
\text { China }\end{array}$ & 0 & 0 & 3225 & 0 & 0 & 0 & 0 & 9132113 & 744 & 9136082 \\
\hline & Land saving & 0 & 0 & -4836 & 0 & 0 & 0 & 0 & 3756442 & -609 & 3750997 \\
\hline \multirow{3}{*}{$\begin{array}{l}\text { From the } \\
\text { US to } \\
\text { Japan }\end{array}$} & $\begin{array}{l}\text { Produced in } \\
\text { the US }\end{array}$ & 49492 & 19803 & 1530255 & 794 & 42203 & 1165 & 114437 & 920101 & 1143114 & 3821364 \\
\hline & $\begin{array}{l}\text { Produced in } \\
\text { Japan }\end{array}$ & 45194 & 43084 & 5742507 & 1054 & 60659 & 720 & 172295 & 1581127 & 951354 & 8597995 \\
\hline & Land saving & -4298 & 23281 & 4212253 & 260 & 18456 & -445 & 57858 & 661026 & -191760 & 4776631 \\
\hline \multirow{3}{*}{$\begin{array}{l}\text { The US } \\
\text { to Mex- } \\
\text { ico }\end{array}$} & $\begin{array}{l}\text { Produced in } \\
\text { the US }\end{array}$ & 13512 & 4 & 856712 & 4268 & 76305 & 86 & 506261 & 1221127 & 880524 & 3558799 \\
\hline & $\begin{array}{l}\text { Produced in } \\
\text { Mexico }\end{array}$ & 20641 & 4 & 2597371 & 6802 & 126503 & 113 & 568953 & 2362737 & 498360 & 6181482 \\
\hline & Land saving & 7129 & 0 & 1740659 & 2533 & 50198 & 26 & 62691 & 1141610 & -382164 & 2622683 \\
\hline \multirow{3}{*}{$\begin{array}{l}\text { From } \\
\text { Argentina } \\
\text { to China }\end{array}$} & $\begin{array}{l}\text { Produced in } \\
\text { Argentina }\end{array}$ & 12669 & 0 & 231 & 0 & 0 & 0 & 1764 & 3062232 & 0 & 3076896 \\
\hline & $\begin{array}{l}\text { Produced in } \\
\text { China }\end{array}$ & 14429 & 0 & 268 & 0 & 0 & 0 & 2240 & 4962496 & 0 & 4979433 \\
\hline & Land saving & 1760 & 0 & 37 & 0 & 0 & 0 & 476 & 1900264 & 0 & 1902537 \\
\hline \multirow{3}{*}{$\begin{array}{l}\text { From } \\
\text { Canada to } \\
\text { the US }\end{array}$} & $\begin{array}{l}\text { Produced in } \\
\text { Canada }\end{array}$ & 131772 & 1588 & 33764 & 613713 & 0 & 45820 & 0 & 109596 & 820789 & 1757042 \\
\hline & $\begin{array}{l}\text { Produced in } \\
\text { the US }\end{array}$ & 116720 & 1773 & 31810 & 774724 & 0 & 64403 & 0 & 103019 & 756988 & 1849437 \\
\hline & Land saving & -15052 & 185 & -1954 & 161011 & 0 & 18583 & 0 & & -63801 & 92395 \\
\hline \multirow{3}{*}{$\begin{array}{l}\text { From } \\
\text { Argentina } \\
\text { to Brazil }\end{array}$} & $\begin{array}{l}\text { Produced in } \\
\text { Argentina }\end{array}$ & 91391 & 0 & 3895 & 0 & 36100 & 24 & 11 & 315 & 1546233 & 1677969 \\
\hline & $\begin{array}{l}\text { Produced in } \\
\text { Brazil }\end{array}$ & 100754 & 0 & 6380 & 0 & 55288 & 30 & 20 & 311 & 1747153 & 1909937 \\
\hline & Land saving & 9363 & 0 & 2485 & 0 & 19188 & 5 & 9 & -4 & 200921 & 231968 \\
\hline \multirow{3}{*}{$\begin{array}{l}\text { From the } \\
\text { US to } \\
\text { Republic } \\
\text { of Korea }\end{array}$} & $\begin{array}{l}\text { Produced } \\
\text { in the US }\end{array}$ & 263 & 44 & 654768 & 475 & 11600 & 4422 & 365 & 193281 & 449706 & 1314923 \\
\hline & $\begin{array}{l}\text { Produced in } \\
\text { Republic of } \\
\text { Korea }\end{array}$ & 418 & 38 & 1292935 & 449 & 12703 & 2806 & 946 & 333690 & 373658 & 2017643 \\
\hline & Land saving & 155 & -5 & 638167 & -26 & 1103 & -1616 & 581 & 140409 & -76048 & 702720 \\
\hline \multirow{3}{*}{$\begin{array}{l}\text { From } \\
\text { Brazil to } \\
\text { Spain }\end{array}$} & $\begin{array}{l}\text { Produced in } \\
\text { Brazil }\end{array}$ & 0 & 0 & 271063 & 54 & 1635 & 0 & 7787 & 793475 & 7 & 1074021 \\
\hline & $\begin{array}{l}\text { Produced in } \\
\text { Spain }\end{array}$ & 0 & 0 & 105264 & 50 & 1045 & 0 & 4621 & 896714 & 5 & 1007699 \\
\hline & Land saving & 0 & 0 & -165799 & -4 & -590 & 0 & -3166 & 103239 & 2 & -66322 \\
\hline \multirow{3}{*}{$\begin{array}{l}\text { From the } \\
\text { US to } \\
\text { Nigeria }\end{array}$} & $\begin{array}{l}\text { Produced in } \\
\text { the US }\end{array}$ & 0 & 0 & 87 & 0 & 3058 & 0 & 0 & 1123 & 1032562 & 1036830 \\
\hline & $\begin{array}{l}\text { Produced in } \\
\text { Nigeria }\end{array}$ & 0 & 0 & 435 & 0 & 12575 & 0 & 0 & 3091 & 618377 & 634478 \\
\hline & Land saving & 0 & 0 & 348 & 0 & 9517 & 0 & 0 & 1968 & -414185 & -402352 \\
\hline \multirow{3}{*}{$\begin{array}{l}\text { From } \\
\text { Australia } \\
\text { to Japan }\end{array}$} & $\begin{array}{l}\text { Produced in } \\
\text { Australia }\end{array}$ & 347358 & 0 & 388 & 16860 & 0 & 0 & 4918 & 104 & 658657 & 1028285 \\
\hline & $\begin{array}{l}\text { Produced in } \\
\text { Japan }\end{array}$ & 191863 & 0 & 855 & 14456 & 0 & 0 & 5293 & 135 & 290267 & 502869 \\
\hline & Land saving & -155495 & 0 & 466 & -2404 & 0 & 0 & 376 & 31 & -368390 & -525416 \\
\hline
\end{tabular}


Brazil exporting soybean to China massively contributes to the land saving. Additionally, exports of maize and wheat from the United States to China also contribute to land saving, but exporting maize from Brazil to China generates land loss at the global scale.

Table 6 exhibits virtual-land flows from the ten largest virtual-land-export countries to the ten largest virtual-land-import countries in which virtual-land flows from the United States to China, from Brazil to China, from the United States to Japan, from the United States to Mexico, from Argentina to China, from the United States to the Republic of Korea, from Brazil to Spain, and from Australia to Japan are larger than 1,000,000 ha/year. As the twelfth largest virtual-land-import country, Nigeria imported 1,036,830 ha/year virtual land from the United States during 1997 to 2011. Additionally, besides being the largest virtual-land-export countries the United States and Brazil import a large area of virtual land every year through international cereal trade. Virtual-land flows from Canada to the United States and from Argentina to Brazil are also larger than 1,000,000 ha/year (Table 5).

Table 6 A matrix of virtual-land flows from the ten largest virtual-land-export countries to the ten largest virtual-land-import countries (ha/year)

\begin{tabular}{lllllllllll}
\hline $\begin{array}{c}\text { to } \\
\text { from }\end{array}$ & Algeria & China & Germany & Japan & Mexico & Morocco & Netherland & $\begin{array}{l}\text { Republic } \\
\text { of Korea }\end{array}$ & $\begin{array}{c}\text { Spain } \\
\text { zuela }\end{array}$ \\
\hline Argentina & 297011 & 3064227 & 12339 & 145593 & 207 & 157409 & 38059 & 19286 & 138130 & 51075 \\
Australia & 9000 & 583643 & 2564 & 1028285 & 0 & 5406 & 0 & 632115 & 21626 & 780 \\
Brazil & 128302 & 5385085 & 285728 & 256728 & 7102 & 155818 & 902309 & 278143 & 1074021 & 18196 \\
Canada & 194716 & 200730 & 48790 & 662470 & 302889 & 191865 & 166028 & 188006 & 80430 & 287538 \\
France & 600470 & 31545 & 280919 & 598 & 840 & 289953 & 563972 & 0 & 397441 & 0 \\
Kazakhstan & 2324 & 0 & 66539 & 699 & 0 & 8490 & 824 & 0 & 6124 & 0 \\
Russian & 6368 & 2108 & 8307 & 18074 & 0 & 39979 & 7298 & 12785 & 55256 & 0 \\
Thailand & 11746 & 112486 & 9465 & 82935 & 42 & 14 & 27118 & 20010 & 12629 & 41 \\
Ukraine & 47181 & 1626 & 14787 & 46115 & 0 & 30327 & 256155 & 179143 & 347056 & 0 \\
US & 130927 & 6925492 & 402548 & 3821364 & 355879 & 245622 & 205316 & 1314923 & 437362 & 364466 \\
\hline
\end{tabular}

Note: The areas of virtual land are calculated by yields of export countries.

Figure 4 shows the 11 most major virtual-land-flow routes (i.e. $>1,000,000$ ha/year). These virtual-land-flow routes are nearly the same with the virtual-water-flow routes explored by Hoekstra and Mekonnen (2012) even though besides agricultural products, industrial products were also included in Hoekstra and Mekonnen's (2012) virtual-water-flow study. A combined consideration of Table 5 and Figure 4 can explore that the United States and Northeast Asia (i.e. China, Japan, and the Republic of Korea) are global centers of virtual-land export and virtual-land import, respectively. Compared to Fader et al.'s (2011) virtual-land-saving study that was conducted for the period of 1998-2002, this study shows that the status of the United States as the global virtual-land export center is not changed while the status of Northeast Asia as the global virtual-land import center becomes more apparent. During 2007 to 2011, 24.81\% of virtual land was absorbed by the three Northeast Asian countries. However, not all cereal trade originating from the United States necessarily generated land saving at the global scale. For example, the cereal trade between the United States and Nigeria generated net land loss at the global scale (Table 6). It can be found (Table 7) that the yield of maize is rather large but that of wheat is relatively small in the United 
States. Consequently, when a large amount of maize is exported from the United States, a land saving at the global scale is very likely to be generated. Yet when a large amount of wheat is exported from the US, the cereal trade is likely to result in land loss at the global scale. Similarly, land loss may occur as well when China, Japan, and the Republic of Korea import cereal. Yields of the eight kinds of cereal are not very small in China, Japan, and the Republic of Korea, and some yields of China, Japan, and the Republic of Korea are even much larger than global averages (Table 7). A major reason for Japan and the Republic of Korea importing large amounts of cereal every year is that their limited territory cannot provide sufficiently large areas of farming land to produce cereal to meet their domestic demands. Despite the small ELD, China's huge population inevitably produces a considerable

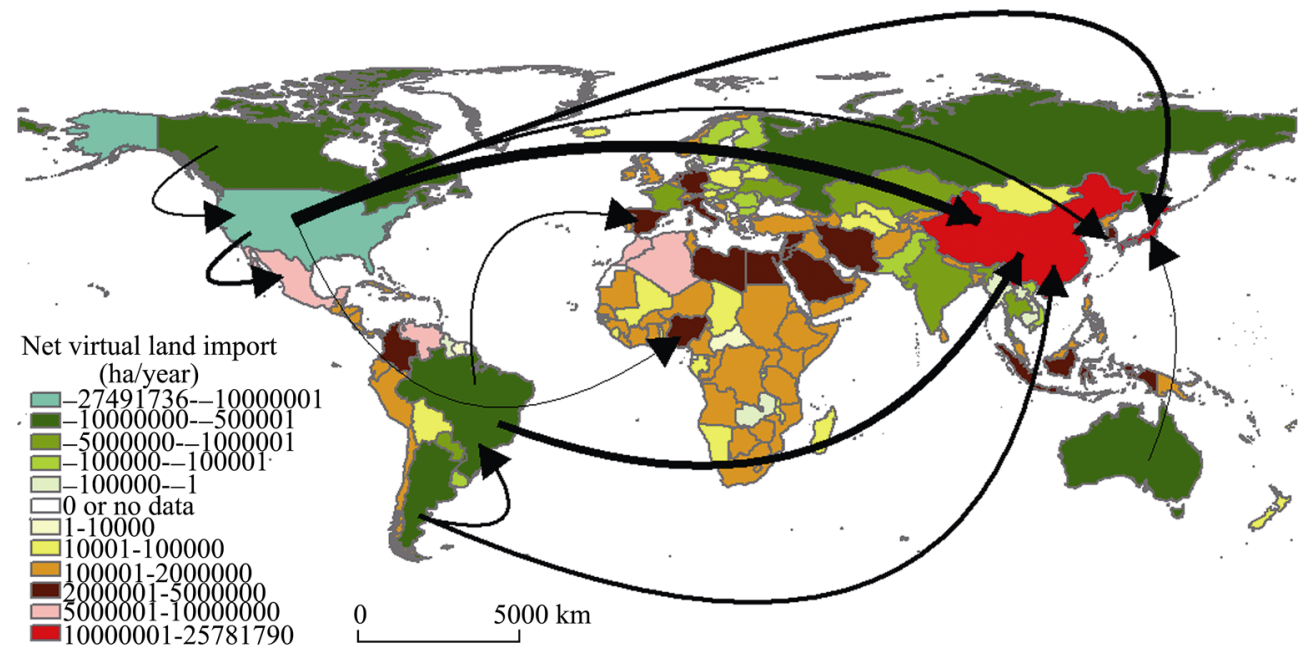

Figure 4 Net imported virtual land per country and directions of virtual-land flow related to international cereal trade over the period of 2007-2011

Note: Only the largest virtual-land flows $(>1,000,000$ ha/year) are shown.

Table 7 Average yields of cereal of the countries that are involved in the 11 largest virtual-land flows over the period of 2007-2011 (hg/ha)

\begin{tabular}{lccccccccc}
\hline & Barley & Buckwheat & Maize & Oats & Rice & Rye & Sorghum & Soybean & Wheat \\
\hline Argentina & 33608 & N/A & 67713 & 18440 & 65654 & 15281 & 45124 & 26307 & 28715 \\
Australia & 17580 & N/A & 55434 & 13785 & 88503 & 5985 & 31559 & 20552 & 15803 \\
Brazil & 29383 & 11606 & 40314 & 20205 & 42969 & 12822 & 23577 & 28670 & 24678 \\
Canada & 31679 & 11500 & 89157 & 28296 & N/A & 23860 & N/A & 26644 & 27436 \\
China & 35883 & 8320 & 54375 & 27444 & 65637 & 30805 & 38360 & 16788 & 47390 \\
Japan & 32215 & 5176 & 25799 & 17232 & 60659 & N/A & N/A & 16432 & 36174 \\
Mexico & 23418 & N/A & 31832 & 15298 & 47504 & 15000 & 36698 & 15423 & 51922 \\
Nigeria & N/A & N/A & 18472 & N/A & 17188 & N/A & 12694 & 9075 & 16697 \\
Republic of Korea & 28139 & 10135 & 48869 & N/A & 71266 & N/A & 16006 & 16760 & 36098 \\
Spain & 30518 & N/A & 103826 & 21333 & 73755 & 21217 & 41459 & 25335 & 32050 \\
US & 36507 & 8785 & 96569 & 22432 & 78329 & 17153 & 41927 & 28357 & 29541 \\
Average of the world & 28101 & 10841 & 43758 & 24022 & 37524 & 28398 & 28674 & 16297 & 30796 \\
\hline
\end{tabular}


dynamic demand on cereal and draws global virtual land to its territory. Therefore, a positive yield difference between export and import countries may not be a major dynamic of a virtual-land flow related to an international cereal trade and international cereal trade does not always result in land saving at the global scale.

\section{Conclusions}

This study highlights that international cereal trade does not only greatly mitigate shortages of domestic arable land resources of individual countries/regions but also saves a considerably large area of land at the global scale.

(1) During 2007 to 2011 international cereal trade generated 50,092,284 ha/year land saving, roughly the size of Spain.

(2) Different cereals contribute to global land saving through international trade differently. Sorghum has the largest land-saving efficiency, but soybean trade saved the largest area of land resources amongst the selected nine cereals. That is due to the fact that soybean enjoys a relatively high land-saving efficiency and accounts for a very substantive portion of international cereal trade during 2007 to 2011.

(3) Although international cereal trade has led to a very large land saving, not all individual cereal trade between two countries save land resource at the global scale. For example, cereal trades from the United States to Nigeria and those from Australia to Japan led to land loss at the global scale. Thus, purely considered from an aspect of saving global land resources, more endeavor is still needed to plan cereal trade among individual countries.

(4) Additionally, we find that countries with very large population (e.g. China and India) are not necessarily dependent on virtual-land import. Domestic arable land area and economic level are also very likely to impact virtual-land flow.

Hence, in the future we will pay special attention to dynamics of virtual-land flow given that this study has shown that population pressure and positive differences on yields between export and import countries may not be crucial dynamics of virtual-land flow. The concept of telecoupling points out that with continued globalization, interactions between distant social and environmental systems is becoming increasingly intense (Liu et al., 2013). The concept of virtual land provides a framework to study the linkage between natural resources in physical spheres and anthropogenic activities in social systems. Thus, this study does not only explore great potential of land saving through international cereal trade but also addresses deeper thinking. In the era of globalization stationary natural resources can be re-allocated spatially through international trades. Future management of natural resources should be planned and executed in combined natural-social systems and not only in physical spheres.

\section{References}

Chapagain A K, Hoekstra A Y, 2004. Water footprints of nations. Value of Water Research Report Series, Vol. 16. UNESCO-IHE, Delft, the Netherlands.

Chapagain A K, Hoekstra A Y, Savenije H H G, 2006. Water saving through international trade of agricultural products. Hydrology and Earth System Sciences, 10: 455-468

Chapagain A K, Hoekstra A Y, Savenije H H G et al., 2006. The water footprint of cotton consumption: An as- 
sessment of the impact of worldwide consumption of cotton products on the water resources in the cotton producing countries. Ecological Economics, 60: 186-203.

Dalin C, Konar M, Hanasaki N et al., 2012. Evolution of the global virtual water trade network. PNAS, 109: 5989-5994.

Fader M, Gerten D, Thammer M et al., 2011. Internal and external green-blue agricultural water footprints of nations, and related water and land savings through trade. Hydrology and Earth System Sciences, 15: $1641-1660$.

Food and Agriculture Organization of the United Nations (FAO), 2014, FAOSTAT, available from: http://faostat.fao.org/ site/567/default.aspx\#ancor (last access: 4/16/2014).

Fraiture C, Cai X, Amarasinghe U et al., 2004. Does international cereal trade save water? The impact of virtual water trade on global water use. Comprehensive Assessment Research Report 4. International Water Manage. Institute, Colombo.

Hoekstra A Y, Chapagain A K, 2007. Water footprints of nations water use by people as a function of their consumption pattern. Water Resources Management, 21: 35-48.

Hoekstra A Y, Chapagain A K, 2008. Globalization of Water: Sharing the Planet's Freshwater Resources. Oxford: Blackwell.

Hoekstra A Y, Hung P Q, 2002. Virtual water trade: A quantification of virtual water flows between nations in relation to international crop trade. Value of Water Research Report Series, Vol. 11. UNESCO-IHE, Delft, the Netherlands.

Hoekstra A Y, Mekonnen M M, 2012. The water footprint of humanity. PNAS, 109: 3232-3237.

Konar M, Dalin C, Hanasaki N et al., 2012. Temporal dynamics of blue and green virtual water trade networks. Water Resources Research, 48: W07509. doi: 10.1029/2012WR011959.

Liu J, Hull V, Batistella M et al., 2013. Framing sustainability in a telecoupled world. Ecology and Society, 18(2): 26.

Qiang W, Liu A, Cheng S et al., 2013. Agricultural trade and virtual-land use: The case of China's crop trade. Land Use Policy, 33: 141-150.

Tilman D, Cassman K G, Matson P A et al., 2002. Agricultural sustainability and intensive production practices. Nature, 418: 671-677.

Würtenberger L, Koellner T, Binder C R, 2006. Virtual-land use and agricultural trade: Estimating environmental and socio-economic impacts. Ecological Economics, 57: 679-697.

\section{Appendix}

Table 1 in appendix Net land saving through cereal trade for 201 countries/regions

\begin{tabular}{llll}
\hline Country & $\begin{array}{c}\text { Net land saving } \\
\text { (ha/year) }\end{array}$ & \multicolumn{1}{c}{ Country } & $\begin{array}{c}\text { Net land saving } \\
\text { (ha/year) }\end{array}$ \\
\hline China, mainland & 25781790 & Chad & 89898 \\
Japan & 11201864 & Madagascar & 88253 \\
Mexico & 6250096 & Mauritius & 76395 \\
Morocco & 6138032 & Belarus & 74177 \\
Algeria & 5283623 & Mali & 74023 \\
Venezuela & 5089433 & New Zealand & 73689 \\
Republic of Korea & 3547290 & Mongolia & 73688 \\
Spain & 3535743 & Bolivia & 72615 \\
Indonesia & 3325665 & Turkmenistan & 67181 \\
Nigeria & 3007082 & Rwanda & 66663 \\
Syrian Arab Republic & 2709493 & Brunei Darussalam & 59237 \\
\hline
\end{tabular}




\begin{tabular}{|c|c|c|c|}
\hline Country & $\begin{array}{l}\text { Net land saving } \\
\text { (ha/year) }\end{array}$ & Country & $\begin{array}{c}\text { Net land saving } \\
\text { (ha/year) }\end{array}$ \\
\hline Iran & 2708283 & Uzbekistan & 57307 \\
\hline Germany & 2656802 & Gabon & 53846 \\
\hline Netherlands & 2599105 & Togo & 53398 \\
\hline Egypt & 2517040 & Slovenia & 50966 \\
\hline Italy & 2511334 & Fiji & 50372 \\
\hline China, Taiwan & 2370107 & Burundi & 45856 \\
\hline Libya & 2288057 & Namibia & 43297 \\
\hline Colombia & 2272798 & Bahrain & 42036 \\
\hline Jordan & 2175838 & Poland & 40525 \\
\hline Saudi Arabia & 2031040 & Barbados & 37782 \\
\hline Iraq & 1898973 & Malawi & 37283 \\
\hline Yemen & 1855308 & New Caledonia & 33984 \\
\hline Peru & 1845530 & Macedonia & 33389 \\
\hline Portugal & 1838485 & Austria & 33355 \\
\hline Turkey & 1682336 & Comoros & 32637 \\
\hline Israel & 1649835 & Guinea-Bissau & 28843 \\
\hline Tunisia & 1516452 & Malta & 25056 \\
\hline Malaysia & 1515052 & Iceland & 21120 \\
\hline Bangladesh & 1464979 & Bhutan & 19551 \\
\hline Philippines & 1334338 & Solomon Islands & 15646 \\
\hline Sudan (former) & 1317915 & Montenegro & 11827 \\
\hline Zimbabwe & 1243656 & Grenada & 9070 \\
\hline Belgium & 1059951 & Saint Vincent and the Grenadines & 8614 \\
\hline Tanzania & 908146 & Timor-Leste & 8285 \\
\hline Ecuador & 873227 & China, Macao & 7430 \\
\hline Cuba & 869336 & Maldives & 6366 \\
\hline Ethiopia & 864130 & Belize & 5246 \\
\hline Dominican Republic & 858426 & Luxembourg & 4693 \\
\hline Kenya & 846853 & French Polynesia & 4131 \\
\hline Mozambique & 831303 & Seychelles & 4054 \\
\hline Somalia & 768800 & Samoa & 4001 \\
\hline Cyprus & 667163 & Central African Republic & 3926 \\
\hline Cameroon & 655903 & Faroe Islands & 3308 \\
\hline Honduras & 632844 & Vanuatu & 3092 \\
\hline Côte d'Ivoire & 617596 & Bahamas & 3085 \\
\hline United Kingdom & 612499 & Equatorial Guinea & 2061 \\
\hline Guatemala & 577794 & Kiribati & 1818 \\
\hline South Africa & 570190 & Sao Tome and Principe & 1562 \\
\hline Azerbaijan & 563093 & Netherlands Antilles & 1540 \\
\hline
\end{tabular}




\begin{tabular}{|c|c|c|c|}
\hline Country & $\begin{array}{l}\text { Net land saving } \\
\text { (ha/year) }\end{array}$ & Country & $\begin{array}{c}\text { Net land saving } \\
\text { (ha/year) }\end{array}$ \\
\hline Costa Rica & 552873 & Guam & 1367 \\
\hline United Arab Emirates & 529476 & Aruba & 1236 \\
\hline Angola & 512591 & Saint Kitts and Nevis & 919 \\
\hline Chile & 499125 & Saint Lucia & 683 \\
\hline Lesotho & 495154 & Suriname & 566 \\
\hline Greece & 467651 & Antigua and Barbuda & 400 \\
\hline Senegal & 463390 & Dominica & 373 \\
\hline Georgia & 420378 & Cayman Islands & 134 \\
\hline Congo, DR & 398694 & Bermuda & 89 \\
\hline Sri Lanka & 388194 & British Virgin Islands & 78 \\
\hline Norway & 385292 & Tonga & 47 \\
\hline Botswana & 337530 & Cook Islands & 27 \\
\hline Ghana & 310273 & Tuvalu & 14 \\
\hline Lebanon & 307742 & Nauru & 12 \\
\hline Panama & 295734 & Saint Pierre and Miquelon & 5 \\
\hline Kuwait & 292829 & Niue & 4 \\
\hline Afghanistan & 292335 & Guyana & -8251 \\
\hline Eritrea & 273103 & Laos & -23863 \\
\hline El Salvador & 257957 & Myanmar & -31085 \\
\hline Jamaica & 247537 & Denmark & -47363 \\
\hline Haiti & 240268 & Cambodia & -51372 \\
\hline Uganda & 227905 & Estonia & -58421 \\
\hline Mauritania & 205813 & Croatia & -61967 \\
\hline Niger & 181457 & Zambia & -64596 \\
\hline Korea, DPR & 175929 & Slovakia & -69767 \\
\hline Armenia & 175220 & Sweden & -121542 \\
\hline Liberia & 171749 & Viet Nam & -123817 \\
\hline Kyrgyzstan & 171738 & Republic of Moldova & -133933 \\
\hline Congo & 171554 & Finland & -163867 \\
\hline Bosnia and Herzegovina & 162307 & Latvia & -174263 \\
\hline Papua New Guinea & 159575 & Czech Republic & -296855 \\
\hline Tajikistan & 154086 & Lithuania & -297548 \\
\hline Occupied Palestinian Territory & 151591 & Serbia & -300503 \\
\hline Ireland & 150592 & Bulgaria & -622897 \\
\hline Guinea & 149275 & Romania & -709695 \\
\hline Benin & 148063 & Pakistan & -763843 \\
\hline Swaziland & 143101 & Uruguay & -900625 \\
\hline Singapore & 141955 & Thailand & -1216772 \\
\hline Oman & 140984 & Hungary & -1218750 \\
\hline
\end{tabular}




\begin{tabular}{lclc}
\hline \multicolumn{1}{c}{ Country } & $\begin{array}{c}\text { Net land saving } \\
\text { (ha/year) }\end{array}$ & Country & $\begin{array}{c}\text { Net land saving } \\
\text { (ha/year) }\end{array}$ \\
\hline Switzerland & 138553 & Paraguay & -2298939 \\
Nicaragua & 137253 & India & -2339266 \\
Cabo Verde & 132540 & France & -3766286 \\
Burkina Faso & 117850 & Kazakhstan & -4555794 \\
Gambia & 115396 & Ukraine & -4758761 \\
Qatar & 114497 & Russia & -6692039 \\
China, Hong Kong & 113223 & Canada & -8115493 \\
Nepal & 106546 & Argentina & -8928639 \\
Djibouti & 101444 & Brazil & -9496388 \\
Sierra Leone & 95590 & Australia & -9922634 \\
Albania & 92221 & US & -27491736 \\
Trinidad and Tobago & 90963 & & \\
\hline
\end{tabular}

Table 2 in appendix External land dependency for 207 countries/regions

\begin{tabular}{|c|c|c|c|}
\hline Country & $\begin{array}{l}\text { Domestic harvested } \\
\text { area (ha/year) }\end{array}$ & $\begin{array}{l}\text { Net virtual-land } \\
\text { import ha/year) }\end{array}$ & $\begin{array}{l}\text { External land } \\
\text { dependency }\end{array}$ \\
\hline Bahrain & 0 & 42036 & N/A \\
\hline Bermuda & 0 & 89 & N/A \\
\hline Aruba & 0 & 1236 & N/A \\
\hline Cayman Islands & 0 & 134 & N/A \\
\hline Cook Islands & 0 & 27 & N/A \\
\hline Equatorial Guinea & 0 & 2061 & N/A \\
\hline Faroe Islands & 0 & 3308 & N/A \\
\hline French Polynesia & 0 & 4131 & N/A \\
\hline Kiribati & 0 & 1818 & N/A \\
\hline China, Hong Kong & 0 & 113223 & N/A \\
\hline Iceland & 0 & 21120 & N/A \\
\hline China, Macao & 0 & 7430 & N/A \\
\hline Nauru & 0 & 12 & N/A \\
\hline Netherlands Antilles & 0 & 1540 & N/A \\
\hline Niue & 0 & 4 & N/A \\
\hline Saint Kitts and Nevis & 0 & 919 & N/A \\
\hline Saint Lucia & 0 & 683 & N/A \\
\hline Saint Pierre and Miquelon & 0 & 5 & N/A \\
\hline Seychelles & 0 & 4054 & N/A \\
\hline Singapore & 0 & 141955 & N/A \\
\hline Tonga & 0 & 47 & N/A \\
\hline Tuvalu & 0 & 14 & N/A \\
\hline British Virgin Islands & 0 & 78 & N/A \\
\hline
\end{tabular}




\begin{tabular}{|c|c|c|c|}
\hline Country & $\begin{array}{c}\text { Domestic harvested } \\
\text { area (ha/year) }\end{array}$ & $\begin{array}{l}\text { Net virtual-land } \\
\text { import ha/year) }\end{array}$ & $\begin{array}{c}\text { External land } \\
\text { dependency }\end{array}$ \\
\hline Samoa & 0 & 4001 & N/A \\
\hline Djibouti & 8 & 101444 & 12680.45 \\
\hline Mauritius & 79 & 76395 & 969.4771 \\
\hline United Arab Emirates & 1348 & 529476 & 392.7864 \\
\hline Barbados & 102 & 37782 & 371.8745 \\
\hline Qatar & 524 & 114497 & 218.5054 \\
\hline Saint Vincent and the Grenadines & 41 & 8614 & 209.0683 \\
\hline Kuwait & 1838 & 292829 & 159.2845 \\
\hline Jamaica & 1812 & 247537 & 136.6398 \\
\hline Maldives & 71 & 6366 & 89.41679 \\
\hline Guam & 17 & 1367 & 82.36963 \\
\hline Oman & 3179 & 140984 & 44.34845 \\
\hline Papua New Guinea & 3649 & 159575 & 43.73127 \\
\hline Brunei Darussalam & 1614 & 59237 & 36.69754 \\
\hline Jordan & 61135 & 2175838 & 35.59059 \\
\hline New Caledonia & 1069 & 33984 & 31.7904 \\
\hline Trinidad and Tobago & 3441 & 90963 & 26.43648 \\
\hline Grenada & 345 & 9070 & 26.30414 \\
\hline Bahamas & 149 & 3085 & 20.67528 \\
\hline Israel & 84125 & 1649835 & 19.61176 \\
\hline Cyprus & 37032 & 667163 & 18.01575 \\
\hline Solomon Islands & 1104 & 15646 & 14.17457 \\
\hline Netherlands & 214211 & 2599105 & 12.13338 \\
\hline Congo & 15033 & 171554 & 11.4115 \\
\hline Fiji & 4416 & 50372 & 11.4068 \\
\hline Antigua and Barbuda & 42 & 400 & 9.512762 \\
\hline China, Taiwan & 274056 & 2370107 & 8.648252 \\
\hline Costa Rica & 71569 & 552873 & 7.725073 \\
\hline Malta & 3418 & 25056 & 7.33072 \\
\hline Libya & 344875 & 2288057 & 6.634461 \\
\hline Portugal & 302005 & 1838485 & 6.087596 \\
\hline Occupied Palestinian Territory & 25614 & 151591 & 5.918301 \\
\hline Lebanon & 56866 & 307742 & 5.411732 \\
\hline Japan & 2082021 & 11201864 & 5.380283 \\
\hline Saudi Arabia & 378857 & 2031040 & 5.36097 \\
\hline Dominican Republic & 194428 & 858426 & 4.415143 \\
\hline Venezuela & 1156968 & 5089433 & 4.398942 \\
\hline Cabo Verde & 31517 & 132540 & 4.205284 \\
\hline Republic of Korea & 1056738 & 3547290 & 3.356831 \\
\hline
\end{tabular}




\begin{tabular}{|c|c|c|c|}
\hline Country & $\begin{array}{l}\text { Domestic harvested } \\
\text { area (ha/year) }\end{array}$ & $\begin{array}{l}\text { Net virtual-land } \\
\text { import ha/year) }\end{array}$ & $\begin{array}{l}\text { External land } \\
\text { dependency }\end{array}$ \\
\hline Belgium & 323792 & 1059951 & 3.273554 \\
\hline Botswana & 116100 & 337530 & 2.907228 \\
\hline Lesotho & 176601 & 495154 & 2.803802 \\
\hline Dominica & 134 & 373 & 2.776378 \\
\hline Yemen & 716132 & 1855308 & 2.590733 \\
\hline Cuba & 347296 & 869336 & 2.503153 \\
\hline Montenegro & 4776 & 11827 & 2.47617 \\
\hline Swaziland & 57835 & 143101 & 2.47432 \\
\hline Malaysia & 681726 & 1515052 & 2.222379 \\
\hline Georgia & 193377 & 420378 & 2.173876 \\
\hline Vanuatu & 1436 & 3092 & 2.153605 \\
\hline Algeria & 2595359 & 5283623 & 2.035796 \\
\hline Colombia & 1117125 & 2272798 & 2.034507 \\
\hline Gabon & 27552 & 53846 & 1.954316 \\
\hline Panama & 159076 & 295734 & 1.859073 \\
\hline Comoros & 19923 & 32637 & 1.638174 \\
\hline Peru & 1180361 & 1845530 & 1.56353 \\
\hline Tunisia & 1064240 & 1516452 & 1.424915 \\
\hline Somalia & 547519 & 768800 & 1.404153 \\
\hline Honduras & 453727 & 632844 & 1.39477 \\
\hline Norway & 305381 & 385292 & 1.261676 \\
\hline Sao Tome and Principe & 1280 & 1562 & 1.220426 \\
\hline Morocco & 5202344 & 6138032 & 1.179859 \\
\hline Armenia & 158815 & 175220 & 1.103296 \\
\hline Ecuador & 836617 & 873227 & 1.043759 \\
\hline Senegal & 471980 & 463390 & 0.981798 \\
\hline Gambia & 118933 & 115396 & 0.970265 \\
\hline Switzerland & 143224 & 138553 & 0.967389 \\
\hline Chile & 525426 & 499125 & 0.949942 \\
\hline Mauritania & 225367 & 205813 & 0.913233 \\
\hline Syrian Arab Republic & 2978814 & 2709493 & 0.909588 \\
\hline Namibia & 49214 & 43297 & 0.87977 \\
\hline Iraq & 2194160 & 1898973 & 0.865467 \\
\hline Egypt & 3071090 & 2517040 & 0.819592 \\
\hline Côte d'Ivoire & 757427 & 617596 & 0.815387 \\
\hline Eritrea & 348968 & 273103 & 0.782603 \\
\hline Liberia & 227792 & 171749 & 0.753975 \\
\hline El Salvador & 357343 & 257957 & 0.721875 \\
\hline Guatemala & 812813 & 577794 & 0.710857 \\
\hline
\end{tabular}




\begin{tabular}{|c|c|c|c|}
\hline Country & $\begin{array}{l}\text { Domestic harvested } \\
\text { area (ha/year) }\end{array}$ & $\begin{array}{l}\text { Net virtual-land } \\
\text { import ha/year) }\end{array}$ & $\begin{array}{l}\text { External land } \\
\text { dependency }\end{array}$ \\
\hline Italy & 3795662 & 2511334 & 0.661633 \\
\hline Zimbabwe & 1897122 & 1243656 & 0.655549 \\
\hline Albania & 144483 & 92221 & 0.638282 \\
\hline Mexico & 9807793 & 6250096 & 0.637258 \\
\hline Azerbaijan & 926739 & 563093 & 0.607607 \\
\hline Spain & 6101613 & 3535743 & 0.579477 \\
\hline Bosnia and Herzegovina & 300516 & 162307 & 0.540096 \\
\hline New Zealand & 136832 & 73689 & 0.53854 \\
\hline Slovenia & 95287 & 50966 & 0.534869 \\
\hline Ireland & 292372 & 150592 & 0.515071 \\
\hline Greece & 1075372 & 467651 & 0.434874 \\
\hline Haiti & 558282 & 240268 & 0.43037 \\
\hline Germany & 6308509 & 2656802 & 0.421146 \\
\hline Cameroon & 1572667 & 655903 & 0.417064 \\
\hline Kenya & 2225932 & 846853 & 0.380449 \\
\hline Sri Lanka & 1044338 & 388194 & 0.371713 \\
\hline Angola & 1389877 & 512591 & 0.368803 \\
\hline Tajikistan & 419941 & 154086 & 0.366924 \\
\hline Mongolia & 216505 & 73688 & 0.340354 \\
\hline Mozambique & 2524021 & 831303 & 0.329357 \\
\hline Bhutan & 64497 & 19551 & 0.303131 \\
\hline Iran & 8977052 & 2708283 & 0.30169 \\
\hline Nicaragua & 465976 & 137253 & 0.29455 \\
\hline Kyrgyzstan & 587278 & 171738 & 0.29243 \\
\hline China, mainland & 95926026 & 25781790 & 0.268767 \\
\hline Guinea-Bissau & 122888 & 28843 & 0.234711 \\
\hline Ghana & 1327241 & 310273 & 0.233773 \\
\hline Nigeria & 13199408 & 3007082 & 0.227819 \\
\hline Burundi & 222385 & 45856 & 0.206202 \\
\hline Congo, DR & 1972782 & 398694 & 0.202097 \\
\hline United Kingdom & 3042437 & 612499 & 0.201318 \\
\hline Macedonia & 170815 & 33389 & 0.19547 \\
\hline Sudan (former) & 6850399 & 1317915 & 0.192385 \\
\hline Indonesia & 17327619 & 3325665 & 0.191929 \\
\hline Philippines & 7039240 & 1334338 & 0.189557 \\
\hline Belize & 28034 & 5246 & 0.187119 \\
\hline Luxembourg & 25402 & 4693 & 0.184755 \\
\hline Tanzania & 4930370 & 908146 & 0.184194 \\
\hline Sierra Leone & 570478 & 95590 & 0.167561 \\
\hline
\end{tabular}




\begin{tabular}{|c|c|c|c|}
\hline Country & $\begin{array}{l}\text { Domestic harvested } \\
\text { area (ha/year) }\end{array}$ & $\begin{array}{l}\text { Net virtual-land } \\
\text { import ha/year) }\end{array}$ & $\begin{array}{l}\text { External land } \\
\text { dependency }\end{array}$ \\
\hline Rwanda & 427070 & 66663 & 0.156093 \\
\hline South Africa & 3663430 & 570190 & 0.155644 \\
\hline Uganda & 1551600 & 227905 & 0.146884 \\
\hline Benin & 1036465 & 148063 & 0.142854 \\
\hline Ethiopia & 6143549 & 864130 & 0.140656 \\
\hline Turkey & 12070141 & 1682336 & 0.13938 \\
\hline Bangladesh & 11938752 & 1464979 & 0.122708 \\
\hline Guinea & 1300539 & 149275 & 0.114779 \\
\hline Korea, DPR & 1556132 & 175929 & 0.113055 \\
\hline Afghanistan & 2933000 & 292335 & 0.099671 \\
\hline Timor-Leste & 101481 & 8285 & 0.081642 \\
\hline Chad & 1191948 & 89898 & 0.075421 \\
\hline Turkmenistan & 909898 & 67181 & 0.073834 \\
\hline Togo & 769537 & 53398 & 0.06939 \\
\hline Niger & 2959222 & 181457 & 0.061319 \\
\hline Madagascar & 1729575 & 88253 & 0.051026 \\
\hline Burkina Faso & 2507613 & 117850 & 0.046997 \\
\hline Austria & 773020 & 33355 & 0.04315 \\
\hline Bolivia & 1896329 & 72615 & 0.038292 \\
\hline Belarus & 1968230 & 74177 & 0.037687 \\
\hline Uzbekistan & 1546120 & 57307 & 0.037065 \\
\hline Nepal & 3155971 & 106546 & 0.03376 \\
\hline Mali & 2399517 & 74023 & 0.030849 \\
\hline Malawi & 1780026 & 37283 & 0.020945 \\
\hline Central African Republic & 211306 & 3926 & 0.018582 \\
\hline Suriname & 50169 & 566 & 0.011272 \\
\hline Poland & 5598390 & 40525 & 0.007239 \\
\hline French Guiana & 2937 & 0 & 0 \\
\hline Montserrat & 16 & 0 & 0 \\
\hline Micronesia & 145 & 0 & 0 \\
\hline Puerto Rico & 313 & 0 & 0 \\
\hline Réunion & 1847 & 0 & 0 \\
\hline Western Sahara & 3210 & 0 & 0 \\
\hline Myanmar & 8791644 & -31085 & -0.00354 \\
\hline Viet Nam & 8793695 & -123817 & -0.01408 \\
\hline Cambodia & 3010111 & -51372 & -0.01707 \\
\hline Laos & 1013995 & -23863 & -0.02353 \\
\hline India & 98280538 & -2339266 & -0.0238 \\
\hline Denmark & 1445560 & -47363 & -0.03276 \\
\hline
\end{tabular}




\begin{tabular}{|c|c|c|c|}
\hline Country & $\begin{array}{l}\text { Domestic harvested } \\
\text { area (ha/year) }\end{array}$ & $\begin{array}{l}\text { Net virtual-land } \\
\text { import ha/year) }\end{array}$ & $\begin{array}{l}\text { External land } \\
\text { dependency }\end{array}$ \\
\hline Pakistan & 12853408 & -763843 & -0.05943 \\
\hline Guyana & 126099 & -8251 & -0.06543 \\
\hline Zambia & 972373 & -64596 & -0.06643 \\
\hline Slovakia & 756406 & -69767 & -0.09224 \\
\hline Thailand & 12551109 & -1216772 & -0.09695 \\
\hline Croatia & 596105 & -61967 & -0.10395 \\
\hline Sweden & 941866 & -121542 & -0.12904 \\
\hline Romania & 5116961 & -709695 & -0.13869 \\
\hline Moldova & 942070 & -133933 & -0.14217 \\
\hline Serbia & 2038082 & -300503 & -0.14744 \\
\hline Finland & 1075940 & -163867 & -0.1523 \\
\hline Russia & 40285302 & -6692039 & -0.16612 \\
\hline Czech Republic & 1470762 & -296855 & -0.20184 \\
\hline Estonia & 289268 & -58421 & -0.20196 \\
\hline Brazil & 41761186 & -9496388 & -0.2274 \\
\hline Kazakhstan & 15545136 & -4555794 & -0.29307 \\
\hline US & 88441963 & -27491736 & -0.31084 \\
\hline Ukraine & 15163800 & -4758761 & -0.31382 \\
\hline Lithuania & 917500 & -297548 & -0.3243 \\
\hline Argentina & 26511894 & -8928639 & -0.33678 \\
\hline Latvia & 507980 & -174263 & -0.34305 \\
\hline Bulgaria & 1712390 & -622897 & -0.36376 \\
\hline France & 9102805 & -3766286 & -0.41375 \\
\hline Hungary & 2664717 & -1218750 & -0.45737 \\
\hline Australia & 19594911 & -9922634 & -0.50639 \\
\hline Canada & 15971880 & -8115493 & -0.50811 \\
\hline Paraguay & 3948183 & -2298939 & -0.58228 \\
\hline Uruguay & 1506166 & -900625 & -0.59796 \\
\hline
\end{tabular}

